\title{
The Impact of Culture on Human Being Evolution
}

\author{
Javad Bahmani ${ }^{1 *}$ and Esmail Shafie ${ }^{2}$ \\ ${ }^{1}$ Department of Political Science \& Sociology, Iran \\ ${ }^{2}$ Department of Political Science and International Relations; Islamic Azad University, Iran
}

Submission: March 10, 2018; Published: May 09, 2018

"Corresponding author: Javad Bahmani, Department of Political Science \& Sociology, Doctoral advisor, Iran, Email: javadbahmanistu@gmail.com

\begin{abstract}
The cultural cohesion in different civilizations affects human behavior. European countries had no specific country and gradually they were released of the dominance of church and based on the new definition created government-nation as top to bottom. In Iran, civilization was strong and even after Islam, they didn't change their language into Arabic, before that they had human community in a country with central government. People were building the governments in this regard. Even in the extension of countries or different invasions, they didn't low their Iranian identity. This study doesn't attempt to compare the civilization and religions but it reviews the underdevelopment causes of Iran with such civil and cultural integration. In new western concept of West, why this nation with thousands years of establishment of government couldn't achieved common human freedom including freedom of speech or democracy in the past decades. Iran had great culture and civilization all around the world and people had important role in this culture and they emphasized mostly on the term "Iran" in this country.
\end{abstract}

Keywords: Intellectual development; Civil society, Global Vision; Capitalism; Human backward

\section{Introduction}

During the history [1], Iran and the world have experience different types of governments. In the west, the transition from feudality to industrialization or bourgeois created a bridge for human being to achieve the worldly government and the spiritual growth was outside the governance conditions. Now, in 21th century, the human instinct is inclined to the general religion and the reason is the presence of numerous numbers in developed countries and their second or third generation has found their extreme inclinations in Daesh. This lost identity was revealed when the double identity index was inclined to extremism to be far from the community irrelevant with their ideals or even takes revenge. This reason is not adequate to combine religion and politics but the world should be careful to face with these types of behaviors and to have correct and thoughtful planning based on the present and previous experiences. The west is encountered with the condition [2] in which there are many atheists and others attempt to have religious government based on the initial elements at the time of a religious prophet. On the other hand, some communities established religious-based governments and with their personal inference attempt to run the country and they were far from the modern community gradually. These communities were managed with the one selected by God or the one connected to God as religious clergymen. They attempted to take power. These countries had no feudalism period and they had no transition to industrialization and this includes the Persian Gulf countries and some African countries. The main question is that to establish security and thought evolution, until when the human being should participate in these tests.

\section{The role of God in generation of communities}

In different religions, God is strong and he can do anything. $\mathrm{He}$ is the creator of creatures. Human being is taught to create an ethic-based man and worship God to remember his creation basis. He wants to be the source of affection and justice. The position of human being is changed from individual to the one managing the community. The capitalism [3] world is not based on justice. In the book, Protestantism, Weber stated one of the motivating factor to collect wealth for human being as creating job for others and merely for the wealth itself or unduly use of wealth. Today, a few of rich people in the world have money more than half of the people all around the world and their aim of creating new jobs is the increase of wealth, their own happiness and the happiness of their relatives. A few people act based on human ethics as emphasized in religious development and only maximum use of wealth is emphasized mostly. The raw materials of some countries are used and their residents are dumped and this emphasizes mostly on the left views. New views to Marxism are increased and the views to destroy or reduce this difference are inclined mostly to weapons.

These communities think that injustice is increased and they are manifested mostly in communism movements or Daesh extremism groups with their barbarian views. God is the source of creation but for a long time, human being has found that he is the main creator of the community. If the community is full of irrational and deep inequality, this creates violence and destroys comfortable life and progress. 
Wall street movement, thousands of movements and the violent fundamentalist groups are the source of pure injustice and they are built by human being. If there is a boundary for freedom in human community and we can not violate the freedom and comfort of others with the name of freedom, the same is true also about asset. Collection of personal asset is useful if it doesn't increase the poverty of others.

\section{Economic freedom and the relevant reviews}

In this study, we don't attempt to find the better methods in economic growth or complete development regarding the views of Keynes, Smith or F Yadman. Here, my main motivation is not using specific statistics and carrying out a brief field research in big cities and different countries. The considerable gap between the countries has challenged the concept of human being. The thought evolutionary trend of human being is under question and it requires a new approach to self, society and economic freedom and wealth distribution in the world. In the current view to the world, only a few people are responsible for energy or mitochondria and others are only responsible for joy and enjoyment in life and they are created to enjoy the life and others experience grief and hardship.

I am not a socialist who believes in pure sociologist and I am not for the current production and distribution of asset in the world. Some group considers that the earth belongs to them and they want all graces for themselves. Wealthy people are far from ethics and the average people instead of making changes have relied on their routine life. The fundamentalists are involved mostly in mass destruction and this view is not suitable. One of the main reasons of this motivation is the imperialism nature of countries to absorb and accumulate assets in their favorite fields and they try to increase their asset to take the political power to retain the framework of their benefits directly or indirectly. What can we do to create balance in distribution or humanity human rights, development of free thought and making the average people wealthy in the world?

Only my view in this regard is not adequate and all elites with their adequate knowledge in different humanities fields should challenge this issue and attempt to provide the conditions for capitalism and distribution of wealth in the world.

\section{Establishment of international fund of supervision on production and accumulation of capital and its global distribution}

As it is observed, this path is very complex as we shouldn't damage the philosophical basis of capitalism based on wealth accumulation in production path or we shouldn't weaken the motivation of the investor and wealthy person. The asset, production and progress should be developed in the complete developed all around the world. The results of one-direction socialism have been shown; the great and reinter states have shown their motivation of backward. The entire challenge is the turning point of development of permanent democracies with the relevant indices with democracy and it is not based on wealth.

Thus the results are extremism, not tolerating each other, strength of civil community via working information, strength of parties not relevant to wealth and deception of people. We should accept that all people with any though school lose their generating power in the development of thought and pluralism in society. Human being is faced with the development of extremism and self-center vies by recognition of the barriers of establishment of democracy and the reasons of convincing people with money to accept dictator and totalitarian governments and indeed, they have sold their human position. The duty of the humanities theorists is establishing an elite and average (economic) community (This is my own Idea). How much we should give freedom to the wealthy people to have their non-productive capital [4] and be inclined to have the most costly houses at the best places and use hundreds of people to keep these places to enjoy their life and this is a part of new slavery. If we accept that capitalism is based on dedicating much asset to people, as the private ownership is a right to encourage investment, what should we do with the great gap? My recommendation as a person interested in institutions in the framework of rationality is to establish an international organization to control capitalism to the areas of the worlds involved in poverty to be supported via UN. This organization evaluates the capital of people and profit ways with the relevant experts in the countries waiting for asset and without any intervention in the asset of people, the paths are determined as the global policy for them, otherwise, investment in the advanced countries is forbidden for them This issue is definite based on the asset of people or companies and by investment in the international organization, poverty is eradicated and democracy and comfort are increased all around the world. This strategy is definite but the coordination of governments and wealthy people need support of their approach and norms establishment.

Dr. Khaniki, lecturer of University, states in No. 12 of the journal of strategic studies of globalization:" The dominant strategy in globalization is horizontal, vertical and spatial integration of the main global industries from the oil industry to transportation and remote communication. This trend is facilitated by transferring asset from center to the surrounding as the World Bank and monetary fund have organized it and this leads to the global mobilization and the risks of investment in private sector is reduced. My direction in this view is not stability of movement to globalization but I believe that capital distribution for economic growth in the developing countries is unsuitable. I think that with my mechanism of international institute, this problem is removed to some extent but it should be accepted by the theorists of political economy and governments.

This view is based on the evolutionary movement of human being to perfection and its performance is rational for the countries. Finally, by increasing the average class in the 
developing countries, rationality and democracy are increased. The challenges of each country include, totalitarian governments, false democracies without creating democracy culture and application of democracy indices in the country, reduction of capitalism power in the political mechanism [5] of countries including entering the parliament or as stated by Trump, viewing politics from the view of trade and considering the political and economic paths by the civil society and the main power in the present world should be at the center of everything. The civil society in each country consists of Senate parliament from the view of each definite class of civil society and supervises the weapon and global poverty with all its power to restrict the marginal governments. Only the civil society perceives its benefits ignoring the interacting political and economic mechanisms and the selected elites of this society reveal their function in each section to keep the benefits of their civil society and it is changed with the qualification of the civil society selecting this person and only the view of civil society as the owners of country can be used in the policy making to use weapons and eradicate poverty at global level with the collaboration of international organization of global poverty eradication. All information structures are free to challenge the decisions and the law should protect this class as specific and general.

\section{Political economy, Achill's heel of development}

If we accept that with all the mutual of effects of economy and politics, economy is the political economy and discussing in this regard is easier and I choose this way. With political event in a part of the world, the stock markets in the countries are affected. The only reason is that asset is also fluctuated. The isolated countries including northern Korea have shown none- development and in any development factor, atomic bomb cannot increase development, unless a country attempts to use it and this leads to the destruction of the country.

All developed countries and those owners of weapons prefer to restore the order of the world and they take the complete path of development for their people. Here, it is defined that the people who prevent the authorities taking any decision are those who should enter at macro level of power and policy making. Only in totalitarian, oligarchy, capitalism-based countries, power is not given to the civil society and there is not much political support. If a country opens its political borders to all countries for export and import, it will have dynamic economy at global level. Some examples are southern Korea in 60s and developing countries such as Malaysia and Singapore. A rich country like Arabia doesn't reach the initial layers of development, cultural development, pluralism and freedom with the domestic and foreign policies. The effect of domestic and foreign politics is shown clearly in these examples. Totalitarian acts and oligarchy cannot open the way to development.

The deep effect of economy and politics is seen here and I call it not economy but political economy in this stage and I hope that all theorists welcome this paradigm-based entrance in economy. At this time, the political economy should be determined and develop democracy all around the world it should aim at the better life and happiness of human being. Thus, all the countries slow in development and political economy growth are involved in a specific point from domestic and foreign politics and have obliged some people to hardship, pain, lack of thought and complete development. Under these conditions, these countries are only dishonor for the rulers and people attempt to change them. I stated in these sentences how Achill's heel of development is political economy. My basis is not the economic growth indices and it is formed varied without any development parameters as one of them is political economy.

\section{The growth of extremism in century 21}

I cannot insert important issues in the present study but I can motivate the thoughts to search for this issue. I don't only see extremism in religious issues regarding Daesh or fundamentalist Islamists. The increase of extremist right parties in Europe is dangerous, why? Because the behavior of fundamentalist Islamists reveals their face really. In America as an active civil society and rich average class, a merchant not perceiving the benefits of his country and the world by the macro political economy level crossing the future and present time can take the power. In France, Macron won in the second round and the extremist right party took a big step. In England, separation is a big issue and it is approved. These signs are warnings for all theorists in which the average class attempts to find the peace, better life, safety and comfort and it needs a review in this attitude. We can unify the world against the fundamentalist Muslims but if the power is given to Trump and Paris agreement is violated, what we can do to reduce the damages.

If the right extremist took power in France, how can we unify the world against its racist behavior and how can we prevent the emergence of another Hitler with the excuse of increasing the wages, increase of immigrants and racial superiority to achieve jobs. I believe that the theorists should attempt to find the best solution in this regard. First, I agree about the entrance of civil society at macro power level, Senate parliament with the supervision on approval of rules and using weapons and political economy path. If this solution is implemented, the historical liability is given to the society itself and populism has no place here. Can we connect the average class outside of the present life to the future and can we explain its role by another method except the active presence in the civil society? These affairs show that the process of education should be taken about the fundamentalists and it should be taken also about these average groups and they should know that as the world is turned into a village in terms of communication, in this village, human being has his own rights and no race or ethnicity is superior to another one and it is hard to repeat all these again in this century and modernity is repeated against and it has stabilized itself gradually. 
Here, some groups believe in the superior race and poverty or other problems can change their political economy, they should be unified and they should know that these views are problematic all around the world. Before any atomic bomb, people destroy each other and the only difference of human being with other creatures is thinking. Also in this way, the difference of human being and super computers as planning and analysis power is lost. We can make our future, as our ancestors have done it for us well. Thus, we should make a happy world for our children and other people.

\section{Conclusion}

This short text requires review in some books and tens of theorists to extend it and it is based on a challenging issues. The present study presents a solution in civil society to stabilize political economy instead of the economy of dealing with the fundamentalism and right extremism party and the qualification of human being to make a better world not from materialistic issues but by loving each other and perception of hardships that we should reduce it considerably. It is recommended to create an organization to cover all economic organizations of UN and the world to send asset to the developing and deprived world, accepting the meaning and indices of development instead of the growth of political economy and finally establishment of some mechanisms to inhibit capitalism [6] and retain motivation of productive investment and we can avoid its unduly accumulation and these affairs are organized by the civil society. Indeed, I don't say to move toward socialism [7] communist, I prefer a solution for consumers and producers, the owners of production tools and the producing worker playing important role in political economy growth. Reduction of tensions of the class gap for the benefit of new socialist and political disorder should be reduced in political economy.

\section{References}

1. (2014) The brief history of economic thoughts, Bosandline (Eds.), New edn, Hamidreza Arbab, Iran.

2. (2014) Government and economic development. Mohammad Delforuz (Eds.), Agah publication, Iran.

3. (2016) Transition from capitalism. In: Saeed Rahnama (Eds.), Parviz Sedaghat, Agah publication, Iran.

4. (2013) Theorists of political economy. In: James Carpo E, Raso David PL Mahmoud Abdollahzade, (Eds.), Sales publications, Iran.

5. Dosoto H (2016) Secret of capital. ( $7^{\text {th }}$ edn), Fereidoon Tafzili, Iran

6. Max Weber (2009) Protestant ethics and capitalism soul. ( $2^{\text {nd }}$ edn), Hami publication, Iran.

7. (2016) Sociology of development with the approach to source. $\left(2^{\text {nd }}\right.$ edn), Rozaneh edition, Iran

This work is licensed under Creative Commons Attribution 4.0 License DOI: 10.19080/ASM.2018.01.555556 